EWELINA NurCZyŃSKA-FIDELSKA

\title{
Opowieści o sile zła, czyli powieść Ladislava Fuksa i film Tadeusza Chmielewskiego
}

Ladislav Fuks (1923-1994) to pisarz czeski, którego powieści były aż czterokrotnie przedmiotem adaptacji dokonywanych przez polskich filmowców, którzy w głębokiej intelektualnie, psychologicznie i moralnie prozie jednego z najwybitniejszych przedstawicieli współczesnej czeskiej literatury odnajdywali inspirację dla swych dzieł.

Były to dwa widowiska telewizyjne będące adaptacjami powieści $P a-$ lacz zwłok (Spalovač mrtvol, 1967); pierwsze zostało zrealizowane w formule szkolnej etiudy przez Tomasza Wiszniewskiego i Andrzeja Wyrozębskiego (PWSFTviT, 1980), drugie, będące już profesjonalnym widowiskiem, wyreżyserował Wojciech Wiszniewski (operatorem był Wojciech Król), przy realizacyjnej współpracy Andrzeja Mellina (emisja - OTV Łódź 27 lutego 1981 r., tydzień po śmierci Wojciecha Wiszniewskiego). Ten telewizyjny spektakl poraził widzów intensywnością niemal apokaliptycznej wizji, surrealistycznym obrazowaniem, które to cechy nadały wykreowanej rzeczywistości symboliczny wymiar, a głównemu bohaterowi, owemu palaczowi zwłok, przydały esencjonalności zła.

Stricte filmowe adaptacje prozy Ladislawa Fuksa to w 1978 r. Wśród nocnej ciszy w reżyserii Tadeusza Chmielewskiego (oryginalny tytuł - Přibĕh kriminálniho rady, 1971, w polskim tłumaczeniu powieść: Śledztwo prowadzi radca Heumann) oraz w 1984 r. Kartka z podróży w reżyserii Waldemara Dzikiego (oryg. Pan Theodor Mundstock, 1963).

Czechosłowacką wybitną filmową adaptację Palacza zwłok wyreżyserował Słowak Juraj Herz w 1989 r., któremu później nie udało się zrealizować napisanych już scenariuszy według takich powieści Ladislava Fuksa, jak właśnie Śledztwo prowadzi radca Heumann i Myszy Natalii Mooshaber (Myši Natalie Mooshabrové, 1970).

Debiutujący w czterdziestym roku życia powieścią Pan Theodor Mundstock Ladislav Fuks ukończył studia filozoficzne, zwieńczone doktoratem 
z psychologii, co, jak podkreślają interpretatorzy jego twórczości literackiej, miało wpływ na wybory tematów i bohaterów oraz dominujący w jego powieściach typ konfliktu. Zdzisław Niedziela pisał: „Fuks jako twórca znalazł własny świat - świat zaułków psychicznych i niezwykłej wyobraźni. Przez długie lata omijał bezpośrednio aktualną tematykę zafrapowany tropieniem źródeł zła, zbrodni i degradacji człowieka"11.

W kilku swych utworach (m.in. w tych, które zaintrygowały polskich filmowców) problem ten rozważał, ukazując gehennę czeskich Żydów, i co w twórczości Fuksa znamienne, czynił to głównie przez perspektywę doświadczeń jednostki, poprzez jej życie wewnętrzne, jej psychikę.

Tytułowy bohater powieści Pan Theodor Mundstock, skazany na zagładę stary biuralista (w filmie Kartka z podróży polski Żyd, Jakub Rosenberg czekający w getcie na transport do obozu koncentracyjnego), podejmuje walkę z paraliżującym go strachem poprzez odwołanie do najprostszych czynności. Pan Theodor, mając świadomość nieuchronnego transportu do obozu, wypracowuje w każdym szczególe sposoby przetrwania - przygotowuje się do przerażającej go drogi, ale i wspiera innych. Głęboko wierzy, że iluzja, nadzieja przetrwania będą pomocne w ostatnich dniach życia. Przypadkowo ginąc pod kołami niemieckiego samochodu, nie zdołał sprawdzić tej wiary.

W swej następnej powieści Palacz zwłok Ladislav Fuks przeniósł swą uwagę z postaci ofiary na kata, człowieka, w którym śledzi rozwój tkwiącego w nim instynktu zbrodni. Karel Kopfrkingl, pracownik praskiego krematorium, bogobojny, wrażliwy na muzykę i troskliwy, choć obłudny, ojciec rodziny, ulega wpływom faszystowskiej ideologii, a w niej antysemityzmowi. Pielęgnuje odkrytą w sobie kroplę krwi niemieckiej i ze zgrozą uświadamia sobie, iż jego żona jest półkrwi Żydówką. Za cenę nowych przywilejów czeski mieszczuch staje się hitlerowskim oprawcą wobec rodziny i dawnych współpracowników w krematorium. Oswojony przez swój zawód ze śmiercią, staje się cynicznym mordercą przeszkadzającej mu w karierze żony i syna, a jego nowi, hitlerowscy mocodawcy znajdują $\mathrm{w}$ nim chętnego wykonawcę zbrodni dokonywanych na skalę masową. Gdyby nie bardzo wyrazisty kontekst ideologiczny „kariery” Kopfrkingla, można by sądzić, iż powieść Fuksa i jej adaptacje są studium narastającego obłędu, opisem koszmarnego snu, który opętał wyobraźnię szalonego człowieka, sprawcy zbrodniczych zdarzeń. Towarzyszący działaniom Kopfrkingla klimat horroru jest, zwłaszcza w literackim pierwo-

1 Zdzisław Niedziela, Twórczość Ladislava Fuksa, [w:] Ladislav Fuks, Wariacje na najniższej strunie, tłum. Maria Erhardt-Gronowska, Wyd. „Śląsk”, Katowice 1980, s. 7. 
wzorze i w filmie Herza, projekcją psychiki szalonego zbrodniarza, rozwoju tkwiących w nim predyspozycji mordercy. Na tym studium obłędu ani Fuks, ani Herz, ani Wiszniewski nie poprzestali. Wszyscy oni mocno akcentowali zło, które przenika podatną nań psychikę, a owo zło ma w tym przypadku swe bardzo konkretne źródła w obłędnej faszystowskiej ideologii.

Nie podejmując się na stronach tego tekstu przypomnienia całej twórczości Ladislava Fuksa, przywołać należy te obecne w niej tropy, które odnaleźć można w powieści Śledztwo prowadzi radca Heumann, a której adaptacją jest film Tadeusza Chmielewskiego Wśród nocnej ciszy.

W uznanej za jego najwybitniejsze dzieło powieści Wariacje na najniższej strunie (Variach pro temnou strunu, 1966) Fuks głównym bohaterem czyni chłopca, który dorasta najpierw w atmosferze austrowęgierskiej tradycji rodzinnego domu, a potem już jako młodzieniec w klimacie takich wydarzeń, jak kryzys monachijski i postępująca faszyzacja rodzimego kraju. Ten polityczny kontekst historii dojrzewania Michała jest ważny, lecz uwaga pisarza-psychologa zostaje skupiona na Michale i jego życiu wewnętrznym, na jego samotności i wrażliwości, które są przyczyną jego ucieczki w świat wyobraźni, kompleksów, a nawet odchyleń od pewnej normy świata dzieciństwa. Rzeczywistość otaczająca chłopca jest jego wyobrażeniem, któremu pisarz nadał walory psychicznej wiarygodności dziecięcego sposobu jej odczuwania. To ważna cecha pisarstwa Ladislava Fuksa, istotna także w powieści Śledztwo prowadzi radca Heumann.

Zbliżając się powoli właśnie do niej, należy skonstatować, że pierwszy odbiór skłania do uznania jej za utwór napisany w konwencji sensacyjno-kryminalnej. Należy też podkreślić, że skłonność Ladislava Fuksa do prowadzenia z czytelnikiem pewnych gier stylistyczno-gatunkowych jest pewną stałą cechą jego pisarstwa. Czytając Palacza zwłok, obcujemy z atmosferą horroru, w Nieboszczykach na balu (Niebožticy na bále, 1972) wkraczamy w świat farsy, a nawet buffo, do spotkań z konwencją kryminału dochodzi w czasie lektur powieści Myszy Natalii Mooshaber i właśnie Śledztwa...

Tłumacz powieści Myszy Natalii Mooshaber, Andrzej Babuchowski, owe właściwości prozy Ladislava Fuksa interpretuje w ten sposób:

Kształt jego powieści rodzi się w zakamuflowanym nieco dialogu z rodzimą i obcą tradycją literacką. To swoiste „kuglarstwo" nadaje utworom Fuksa wieloznaczną wymowę, choć przyznać trzeba, że nigdy nie prowadzi do całkowitego immoralizmu i że cała ta twórczość jest głęboko humanistyczna, zaangażowana (w jak najlepszym tego słowa znaczeniu), dyskretnie współczująca. [...] Autor zastawia 
pułapki na schematy myślowe, na obiegowe wyobrażenia o ludzkiej naturze, psychice, moralności, na uproszczone pojmowanie dobra i zła. W potrzask wpadają też przy lekturze nasze nawyki czytelnicze, upodobania do „czystości gatunku”, jednoznacznej wymowy ideowej itp. ${ }^{2}$

Te wyżej wskazane cechy prozy Ladislava Fuksa towarzyszą także lekturze powieści Śledztwo prowadzi radca Heumann³. Stricte kryminalna historia wypełniona jest w niej głębokimi obserwacjami i diagnozami psychologicznymi. Dramatyzm fabuły wspiera się na konflikcie nastoletniego syna z ojcem, klasycznym radca, wysokim komisarzem policji. Chłopiec, maturzysta Viki, przypomina Michała, bohatera powieści Wariacje na najniższej strunie. Obaj (ojciec Michała też jest wysokiej rangi policjantem) są $\mathrm{w}$ rodzinnych, pełnych materialnego dobrobytu domach przeraźliwie samotni. Michał ucieka w świat wyobraźni i skąpych tak naprawdę wspomnień, Viki zaprzyjaźnia się z jeszcze bardziej niż on zamożnymi rówieśnikami, rodzeństwem Barrym i Gretą Piret. Ich dom, za jego nowobogactwo, radca Heumann obdarza pogardą. Viki lgnie do przyjaciół, z którymi spędza wolne chwile, także te $\mathrm{w}$ restauracjach, ale, nade wszystko, snuje plany wspólnej wakacyjnej wyprawy do Turcji, w której ojciec Barry'ego prowadzi intratne interesy i która w marzeniach Vikiego ma stać się stałym miejscem jego ucieczki z rodzinnego domu.

Przyjaźń z Piretami rekompensuje chłopcu chłód i pustkę rodzinnego domu, w którym wychowywany przez owdowiałego ojca może z ukrycia śledzić jego zawodowe poszukiwania, skoncentrowane na śledztwie dotyczącym odnalezienia sprawcy morderstw dokonywanych na dzieciach. Zachęcany przez szkolnych kolegów, zamierza sam równolegle owo śledztwo prowadzić, lecz, jak się okazuje, przekracza to jego możliwości. Rozdrażniony, zagubiony Viki swe samopoczucie wspiera odnalezionymi pigułkami zmarłej matki.

Wśród smutnych tajemnic willi radcy Heumanna, którego gabinet jest centrum domu, Vikiego najbardziej intryguje zbiór starej broni, a zwłaszcza jeden z pistoletów mający swą, także dość tajemniczą, historię z lat młodości jego ojca. To pistolet z lewoskrętną lufą, zwany meyerbachówką, a więc taki, z którego zginęła trójka zamordowanych dzieci. Meyerbachówki były bronią, którą posługiwali się przed wielu laty członkowie Studenckiego Kółka Strzeleckiego, a wśród nich późniejszy

2 Andrzej Babanowski, Posłowie, [w:] Ladislav Fuks, Myszy Natalii Mooshaber, tłum. tenże, Wyd. Literackie, Kraków 1983, s. 352-353.

3 Wydanie polskie w tłumaczeniu Emilii Witwickiej, Czytelnik, Warszawa 1981. 
radca Heumann i jego obecny, znienawidzony przezeń sąsiad, preparator i konserwator szkieletów - Bernard Raster. To z nim, na przekór ojcu, zaprzyjaźnia się Viki. W opowiadanej historii to Raster staje się jednym z podejrzanych, jemu to Viki przedstawia inny, odnaleziony w dokumentach ojca, trop śledztwa - policja poszukuje niejakiego Anatola Brikciusa, który po ucieczce z więzienia w Brukseli przebywa gdzieś w kraju. Radca Heumann i jego współpracownicy w tym, według posiadanej opinii, niespełna rozumu przestępcy widzą mordercę dzieci.

Nadchodzą święta Bożego Narodzenia, ojciec Vikiego złagodniał, nie wspomina przyjaciół syna i ich wspólnych wakacyjnych planów, którym wcześniej kategorycznie się sprzeciwiał. W domu rodzinnym Viki ma jednak opiekuna - jest nim dość tajemniczy kamerdyner, który wspiera chłopca w jego śledczych poczynaniach i marzeniach o Turcji. W wigilijny wieczór radca zaskakuje i Vikiego, i starego kamerdynera zaproszeniem na kolację gości, w tym rodziców jednego z zabitych dzieci. Spotkanie przebiega spokojnie, choć jego głównym tematem są dokonywane morderstwa.

Mijają zimowe miesiące we względnym domowym spokoju, który tyle samo cieszy chłopca, ile niepokoi. Czytelnik już rzadziej obcuje z Vikim, z jego marzeniami i nastrojami. Narrator skupia uwagę na śledczych poczynaniach radcy, który wprawdzie poleca dalsze intensywne poszukiwania Brikciusa, prawdopodobnego mordercy dzieci, lecz coraz więcej uwagi poświęca innym tropom towarzyszącym mordom trójki dzieci: broni, z której je popełniono, owej meyerbachówce, znajdującej się także w jego zbiorach; małej zabawce, pozostawianej przez mordercę przy dzieciach i innym znalezionym śladom (rękawiczki, włókna, sztuczne wąsy). Pogrążony w swych długich rozmyślaniach i analizach radca Heumann pewnego kwietniowego dnia zaprasza syna na przejażdżkę samochodem w miejsce, gdzie tego popołudnia ma być aresztowany Brikcius. Szczęśliwy z powodu tej nieoczekiwanej, pierwszej z ojcem w życiu wyprawy, Viki nie ukrywa pewnego zdziwienia jej okolicznościami. W oczekiwaniu na moment aresztowania przestępcy, na przewróconym pniu drzewa prowadzą swą ostatnią, pełną ciepła rozmowę, w czasie której radca Heumann strzałem, właśnie z meyerbachówki, w tył głowy syna - zabija go. Odkrył bowiem mordercę trzeciego dziecka.

Ostatnie rozdziały powieści zamykają prowadzone przez radcę śledztwo - Brikcius, jako faktyczny zabójca pierwszej dwójki dzieci, już w więzieniu zostaje otruty przez Heumanna. Nie dopuszcza on do rozwiązania tajemnicy trzeciego morderstwa, którego sprawcą był Viki i tego czwartego, ostatniego, dokonanego przezeń na własnym synu. Ocala w ten 
sposób honor rodziny i swój własny, rezygnuje też ze sprawowanej przez siebie funkcji. Spaliwszy wszystkie ślady synowskiej zbrodni, zmożony bólem i zmęczeniem, radca Heumann zasiada w fotelu swego domowego gabinetu, a jego myśli tak podsumowuje narrator:

Co miało zostać ukarane, zostało ukarane, sprawiedliwości stało się zadość. Radca wiedziat, że ręce ma czyste jak dawniej, ale wiedział zarazem, że raz na zawsze jest napiętnowany, jak chyba nikt. Wiedziat, że swoim czynem uratowat honor rodziny, ocalit jej nieposzlakowane imię, a także oczyścił swe sumienie. Czy jednak czyste sumienie warte było tej potwornej grozy, tego najokrutniejszego piętna, którego zmyć się nie da, a które naznaczyło jego duszę

Opowiedzenie kryminalnej historii, a zwłaszcza jej spuentowanie, jest wobec czytelnika swoistym przestępstwem. Rzecz w tym, że w przypadku śledztwa, które prowadzi radca Heumann inaczej się nie da, a to dlatego, że powieść Ladislava Fuksa, choć zbudowana na kryminalnej intrydze, jest tak naprawdę powieścią psychologiczna, której niuanse wymagają ścisłego dopowiedzenia w jej warstwie fabularnej; jest także opowieścią o buncie jednostki wobec tyranii.

Dramatyczna historia radcy Heumanna i jego syna, zachowując schemat powieści kryminalnej, jest kolejną w twórczości Fuksa próbą analizy okoliczności sprzyjających rodzeniu się zła i przemocy. Są one inne, co oczywiste, w Palaczu zwłok i inne w Śledztwie..., ale w obu powieściach ciśnienie okoliczności zewnętrznych na proces destrukcji psychiki bohaterów jest ukazane bardzo wyraziście, choć Karel Kopfrkingel jest człowiekiem dorosłym, zdawałoby się przygotowanym do trudnych wyborów, a Viki Heumann stoi dopiero u progu dorosłości. W Palaczu zwłok kreator tragicznych wydarzeń Kopfrkingel działa zarażony faszystowską ideologią; Viki jest chłopcem bezbronnym, którego osacza rygor ojcowskiej postawy, samotność i obcość w rodzinnym domu. To te okoliczności prowadzą do degradacji jego osobowości i jej tragicznych skutków.

Psychologiczne portrety Vikiego i jego ojca, klimat relacji pomiędzy nimi stanowią główną materię Śledztwa..., a znakomicie poprowadzone wątki kryminalne i ich zaskakująca puenta budują bieg zdarzeń i ich tajemniczość. Wydaje się jednak, że główną cechą tej powieści jest właśnie jej głęboki psychologizm. Ladislav Fuks powrócił w niej do podjętych już w Wariacjach... analiz psychiki czasu dorastania i w jego przekonaniu fundamentalnej dla kształtowania osobowości człowieka relacji z rodzicami, w przypadku obu tych powieści - z ojcami.

4 Ladislav Fuks, Śledztwo prowadzi radca Heumann, s. 309. 
Uniwersalizm tej opowieści i postawione w niej diagnozy Fuks podkreśla nie tylko perfekcyjnie poprowadzoną, pełną ukrytych napięć intrygą kryminalną, nie tylko głębokimi w swych sensach portretami ojca i syna oraz relacjami pomiędzy nimi. Decyduje o nich także zawieszenie akcji w czasie, a zwłaszcza przestrzeni. Czas powieści to współczesność, zapewne lat 60 . W świecie bohaterów są obecne telewizory i tranzystory, ówczesne nowe modele samochodów, rytm niedużego miasta i otaczająca je sielska przyroda, możliwość zagranicznych podróży. Nie jest to jednak rzeczywistość Czechosłowacji tamtych lat. Można by założyć, że miejscem akcji powieści są Niemcy - wiele w niej niemiecko brzmiących nazw miejscowości i nazwisk postaci (ta ostatnia właściwość to jednak cecha wielu powieści Ladislava Fuksa); postacie policjantów - radców i komisarzy to także figury z niemieckiej społecznej kultury. Mimo tych rozsypanych w powieści znaków cywilizacyjnych, czytelników nie opuszcza uczucie, iż przedstawione w niej zdarzenia toczą się „gdzieś i kiedyś".

Wrażenie to potęguje także kompozycja powieści i mimo kryminalnej intrygi, niespieszność jej akcji. Śledztwu... nie towarzyszy dynamika narracji, powieść zawiera wiele powtarzalnych, czasem wariantywnych sytuacji, zdarzeń, a nawet dialogów. Pojawiają się w niej postacie, które w biegu wydarzeń znikaja, co jest sposobem odczuwania świata przez Vikiego. Potwierdzeniem tego wrażenia jest też stała obecność starego kamerdynera, jedynego w rzeczywistości samotnego chłopca współistniejącego z nim człowieka.

Te cechy Śledztwa... potwierdzają, iż nie wątek kryminalny decyduje ostatecznie o gatunkowej przynależności tej powieści. Prowadząc z czytelnikiem niezwykłą, właśnie gatunkową grę, zachwycając niuansami języka narracji, Ladislav Fuks przymusza go niejako do innego stylu odbioru. Psychologiczne walory tej powieści muszą w nim dominować, podobnie jak przeczucie, iż jest to metaforyczna opowieść o źródłach zła, które tkwią w każdej postaci tyranii i przemocy.

$$
* \quad * \quad *
$$

Dokonana w 1978 r. przez Tadeusza Chmielewskiego (był także autorem scenariusza) adaptacja powieści Ladislava Fuksa była pewnym zaskoczeniem, choć krytycy powinni pamiętać, że w minionych latach reżyser ten dwukrotnie mierzył się z tematem zbrodni. Po raz pierwszy uczynił to, realizując w 1960 r. groteskową komedię kryminalną Walet pikowy, czyli kobieta zmienna jest według powieści Czecha Zděnka Jirotki pt. Człowiek 
z psem, po raz wtóry, reżyserując w 1962 r. Dwóch panów „,N", thriller milicyjny, który był ówczesną rodzimą odmianą filmu policyjnego. W przypadku obu tak różnych gatunkowo filmów, które nie zyskały jednak zainteresowania widzów, krytycy, także po latach, podkreślają ich ciekawą wielowarstwową konstrukcję, precyzyjną narrację, akcję trzymającą w napięciu i zaskakujące jej finały ${ }^{5}$.

Pozostałe filmy Tadeusza Chmielewskiego to przede wszystkim cieszące się przez dziesiątki lat ogromną popularnością komedie. Są to m.in.: debiut reżysera, czyli satyryczno-surrealistyczna Ewa chce spać (1957), dwie przygodowo-wojenne komedie Gdzie jest generał (1963) i Jak rozpetatem II wojne światowa (1969), w których dominuje konwencja farsy, i wreszcie Nie lubię poniedziałku (1971), komedia zazębiających się niezwykle sprawnie epizodów, w których satyra na czasy PRL-u przypomina konwencje filmów Stanisława Barei. Ostatnim, zrealizowanym przez Tadeusza Chmielewskiego filmem jest wybitna adaptacja (1983) powieści Stefana Żeromskiego Wierna rzeka.

Jako artysta kina, Chmielewski zajmuje się także scenariopisarstwem i to nie tylko dla swych filmów. Podkreślam ten ostatni nurt twórczości Chmielewskiego, gdyż ta jego umiejętność jest na pewno jednym ze źródeł sukcesu, jakim była adaptacja powieści Ladislava Fuksa, czyli film Wśród nocnej ciszy.

Tadeusz Chmielewski - scenarzysta, a potem reżyser, na pozór zdradził złożoną, o czym była wcześniej mowa, konwencję powieści Śledztwo prowadzi radca Heumann. Jej czasoprzestrzenne niedopowiedzenia ukonkretnił; skoncentrowany na psychologicznych aspektach opowiadanej historii kunszt i rytm narracji sprowadził do wymogów filmowej dramaturgii, dodajmy - kryminalnego thrillera; ograniczył, co jest tak częstym adaptacyjnym zabiegiem, liczbę występujących w powieści postaci (tu żal jedynie starego kamerdynera, osoby tak ważnej w utworze Fuksa przy budowaniu portretu Vikiego, a także i jego ojca).

Świadomie w powieści niedookreślony czas i miejsce akcji, w filmie Tadeusza Chmielewskiego, również dla jego artystycznych celów, przybrały bardzo wyraziste kształty. Mroczną, a w swym finale, tragiczną fabułę filmu budują przestrzenie pomorskiego miasta w Polsce lat 20. Określenie „budują" nie jest w tym przypadku przejęzyczeniem. Owe przestrzenie są elementem tragicznych zdarzeń. To wszystko, co się zdarzyło, być może nie

5 Por. Artur Majer, Tadeusz Chmielewski - zmyst precyzji, [w:] Polskie kino popularne, red. Piotr Zwierzchowski i Daria Mazur, Wyd. UMK, Bydgoszcz 2011. 
stałoby się, gdyby nie klimat ich miejsca. I to nie o aurę tu chodzi, o przysypane śniegiem uliczki miasta i małego portu, o groźną w zimowym pejzażu rzekę. Kilkakrotnie sielskie obrazy przyrody w powieści Fuksa, tu stają się esencją zimowej mroczności; jej gęstość przytłacza, a o to twórcom filmowego thrillera chodziło. Znakomite w swej konwencji zdjęcia Jerzego Stawickiego wydobywają te cechy zimowej pomorskiej architektury i pejzażu (ich przykładem był w filmie głównie Toruń i Bydgoszcz), które stają się istotnym elementem przedstawianego dramatu, właśnie zagęszczającym jego atmosferę. Miłośnicy kina dostrzegą w filmie Chmielewskiego atmosferę filmu $M$ - morderca (1931) Fritza Langa, a w jednej ze scen niemal cytat z tego filmu. Chmielewski oddaje hołd mistrzowi niemieckiego kina, lecz jednocześnie wskazuje intelektualną i estetyczną z nim wspólnotę.

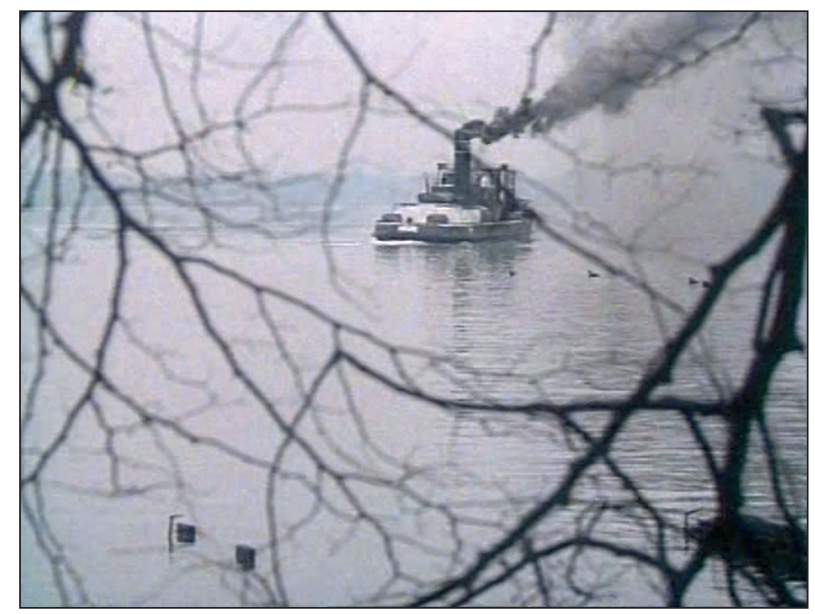

Fot. 7. Wśród nocnej ciszy (1978, reż. Tadeusz Chmielewski) Ponury zimowy pejzaż buduje gęstą atmosferę filmu

Sytuując akcję filmu w Polsce odległych lat 20., Tadeusz Chmielewski przydał przedstawianej historii, inaczej aniżeli uczynił to Ladislav Fuks, także pewnego uniwersalizmu sensów złej relacji pomiędzy ojcem i synem. Choć Wśród nocnej ciszy można uznać za najwybitniejszy w polskim kinie film zrealizowany w stylu „retro”, owo „retro” pełni w nim nie tylko funkcję estetyczną. Pozwala w ciekawy sposób uwiarygodnić opowiadaną historię, przydać jej właśnie znaczeniowego uniwersalizmu, mówiącego, tak jak w powieści Fuksa, o niszczącej jednostkę sile zła płynącego z każdej formy przemocy, nawet wówczas, gdy - co w filmie jest silniej 
podkreślone - intencja tego, który posługuje się ową, choćby domową tyranią, jest w swych założeniach sprawiedliwa, a nawet szlachetna.

Owe lata 20. tworzą w filmie pewien intelektualny dystans wobec przedstawionego dramatu. Jego bohaterowie są bowiem obdarowywani pewną kulturową innością. Decydują o tym cywilizacyjne znaki ulic, po których chodzą bohaterowie; domów, w których mieszkają; marek samochodów, sklepów, a także strojów, które są ich codziennością. Widz obcuje z wdzięczną kobiecą modą, z czarnymi surdutami śledczych ze świata komisarza Hermana (takie, łatwiejsze do odczytania dla polskiego widza nazwisko nosi ojciec Wiktora, właśnie Wiktora, a nie Vikiego), widzi mundury policjantów czasu międzywojnia oraz szkolne mundurki Wiktora i jego kolegów. Wiele w tym filmie także znaków obyczaju, osobistej kultury bohaterów, i tych dorosłych, i tych młodzieńczych, zachowań podwładnych, a nawet serwującej posiłki służącej-gospodyni. W tym także względzie to inny świat, który jednak w niczym nie zmienia przenikającej film atmosfery grozy, z jej, mimo wszystko, zaskakującym finałem.

Jest on tożsamy z fabułą powieści Ladislava Fuksa, choć ona wydaje się psychologicznie bardziej "duszna”. Tadeusz Chmielewski - scenarzysta i reżyser, bardziej aniżeli Fuks wyeksponował w swym filmie samą intrygę kryminalną. Tego wymagały dramaturgiczne zasady kryminalnego thrillera i jego właściwości gatunkowe. Chmielewski nie realizował filmu psychologicznego, choć portrety bohaterów nie zacierają owej, właśnie psychologicznej ich wiarygodności.

Wiktor pozostając samotnym dzieckiem, także oczekuje ojcowskiej serdeczności i na jej najmniejsze okruchy reaguje spontanicznie. Abstrakcyjne w powieści Fuksa marzenia o wyprawie do Turcji, w filmie Chmielewskiego osadzone są w realiach miejsca, w którym Wiktor żyje. Nadrzeczny w miasteczku port jest bramą do wielkiej z przyjacielem Bernardem wakacyjnej wyprawy na morze, w nim także chłopcy miesiącami przygotowują niezbędną dla niej łódź. Przybywający z Gdańska handlowy statek i właśnie owa łódź staną się miejscami, w których Wiktor upatruje szansy na ucieczkę z domu. Staną się też miejscem kryjówki Stopka, bandziora i mordercy pierwszej dwójki dzieci. To z nim Wiktor łączy swe nadzieje na wyrwanie się z domu, choć z dokumentów ojca wie, że Stopek jest poszukiwanym mordercą. W filmie Chmielewski, bardziej niżeli Fuks w powieści, wyraziście ujawnia motywy postępowania chłopca, który dla własnych celów, ale i w akcie zemsty na ojcu, chroni Stopka i z tych samych powodów popełnia zbrodnię. Liczy, że trzecie morderstwo zniszczy karierę ojca, a jego wyzwoli. 
Stopek jest w finale filmu postacią ważniejszą aniżeli powieściowy Brikcius, którego radca Heumann otrut, by tajemnice późniejszych morderstw się nie ujawniły. Inna rola postaci Stopka pozostaje w filmie w ścisłym - choć innym niż w powieści - związku z postacią ojca. To jego komisarz Teofil Herman uczyni wykonawcą wyroku na sobie. Filmowy śledczy nie chce żyć dłużej ze świadomością zbrodni, którą popełnił, zabijając syna w imię sprawiedliwości, ale i bezbrzeżnego lęku o dalszy jego los po ujawnieniu prawdy o trzecim morderstwie.

Postać Teofila Hermana, w przejmującej kreacji Tomasza Zaliwskiego, nie jest tak bezwzględna, jak radcy Heumanna w powieści, choć wobec syna popełnia, podobnie jak tamten, grzechy. Film przynosi, poza ostateczną decyzją bohatera, wiele innych informacji o nim. Jest, jak syn, osobą bardzo samotną - w nieudanym małżeństwie; jego skłonna do romansów i zabaw żona popełniła samobójstwo. Znienawidzony w powieści preparator Raster, w filmie jest dawnym przyjacielem Hermana z czasów, gdy jako policyjny lekarz z nim współpracował, choć zapewne miał romans z jego żoną. Dziś z daleka czuwa nad Wiktorem, a przerażony biegiem spraw Herman składa mu wizytę, wspominając dawną przyjaźń. Teofil Herman ma w swej śledczej pracy jednego autentycznego i lojalnego przyjaciela - komisarza Stefana Wańka (w tej roli bardzo wiarygodny Henryk Bista). On jeden zna tragiczną tajemnicę domu Hermanów, on, wbrew rozkazowi nadkomisarza, a w imię owej przyjaźni, zamknie tę tajemnicę na zawsze.

Przypuszczać należy, że łagodniejszy wizerunek komisarza Hermana - po części odkrywający motywy jego postępowania, po części każący choć trochę je rozumieć oraz ostateczna decyzja, w której sam na siebie wydaje wyrok - to wynik świadomości scenarzysty i reżysera, dotyczącej gatunkowych wymogów filmu, który zrealizował. W kryminalnej historii zło, najczęściej, musi być ukarane, w tej - to zło objęło i syna, i ojca. Obaj musieli zatem $\mathrm{w}$ finale filmu zginąć.

Ladislav Fuks, pisząc powieść psychologiczną jedynie wspartą na kryminalnej konstrukcji, mógł tak naprawdę immoralną postać komisarza Heumanna opisać inaczej, a jego samego pozostawić żywym, choć przytłoczonym piętnem tego, co się zdarzyło, co sam uczynił. Heumann ratował swój i rodzinny honor, Herman zginął świadomie, ogarnięty ojcowską rozpaczą, ale przecież także wierny swemu zawodowemu posłannictwu.

Czy kryminalna formuła filmu Wśród nocnej ciszy zniszczyła psychologiczno-etyczne walory pierwowzoru? Nie, gdyż dramatyczna historia relacji ojciec-syn pozostała przypowieścią, ale właśnie przypowieścią 
o klęsce tyranii, o konsekwencjach zaniku uczuciowych kontaktów między ludźmi, także tymi, zdawałoby się, najbliższymi. Powieść Ladislava Fuksa przez swe niedopowiedzenia, przez narracyjną złożoność opowiedzianej historii, przez swą puentę ma pewne cechy moralitetu; nawet więcej, jest uogólniającą metaforą każdej formy tyranii. Film Tadeusza Chmielewskiego, perfekcyjnie obdarowany gatunkowymi cechami kryminalnego thrillera, $\mathrm{w}$ tym suspensem, takich ambicji nie posiada, ale pozostaje, o czym była już wyżej mowa, przy powieścią o źródłach zła. W niej jest też miejsce na uczucia, które ze stron powieści Fuksa nie przenikają do czytelnika. Rozpacz i miłość na pozór kostycznego ojca Tadeusz Chmielewski wydobył przejmująco; scena zabójstwa syna jest esencją tych uczuć. Niewątpliwie to także zasługa koncepcji postaci, w której swój udział miał Tomasz Zaliwski; to również dzieło młodziutkiego Piotra Łysaka, aktorsko przekonującego w portretowaniu Wiktora, którego ostatnie kadry przed śmiercią bohatera są - w kontekście wszystkich zdarzeń - szokujące swą niewinnością i pięknem.

Tę scenę śmierci Wiktora otacza cały pejzażowy, zimowy klimat filmu, tak perfekcyjnie wykreowany kamerą Jerzego Stawickiego, jej przytłaczającą wymowę buduje jednak napięcie, ów suspens, tak ważny w kształtowaniu narracji kryminalnego thrillera. Widz, tak jak wcześniej czytelnik, przeżywa w tej scenie szok, w obrazie filmowym silniejszy, bo wsparty przynależnymi tylko kinu środkami estetycznymi.

Dokonując, najczęściej nieuchronnych, porównań pomiędzy filmową adaptacją a jej literackim pierwowzorem warto zwrócić uwagę na cele i sensy samych tytułów dzieł. Ladislav Fuks obdarował swą powieść tytułem Přiběh kriminálniho rady (Śledztwo prowadzi radca Heumann). To świadome przez Fuksa wskazanie śledczego chłodu opowiedzianej historii i charakterystyki dorosłego jej bohatera. Tadeusz Chmielewski tytułem Wśród nocnej ciszy nie tylko określił jednorodny czas akcji swego filmu, lecz także przydał przedstawionej tragedii pewien znaczeniowy i emocjonalny kontekst. Dramatowi relacji ojciec-syn i popełnionym zbrodniom towarzyszą najpiękniejsze kolędy, wsparte adekwatną muzyką Jerzego Matuszkiewicza. Tym samym reżyser dookreślił sensy swej pozornie, choć perfekcyjnie poprowadzonej, tylko kryminalnej historii. Idylliczna atmosfera świąt Bożego Narodzenia nie stała się przeciwwagą zła, które wkroczyło w ludzkie dusze. Kryminalny thriller stał się także moralną przypowieścią o sile tego zła. 